\title{
AKUPUNTUR METODE YNSA DAN HIPNOTERAPI TERHADAP KECERDASAN INTELEKTUAL (IQ) DAN KECERDASAN EMOSIONAL (EQ) ANAK
}

\author{
Maria Dewi Christiyawati ${ }^{1)}$, Estuningsih ${ }^{2)}$ \\ 1,2 Poltekkes Kemenkes Surakarta \\ e-mail : mariadewichristiyawati@yahoo.co.id
}

\begin{abstract}
ABSTRAK
Kecerdasan intelektual (IQ) membantu seseorang untuk mampu bertindak secara terarah, berpikir secara rasional, dan menghadapi lingkungannya secara efektif. Sama dengan IQ, kecerdasan emosional (EQ) penting bagi keberhasilan seseorang untuk berempati, mengungkapkan dan memahami perasaaan, mengendalikan amarah, kemandirian, serta beradaptasi. Beberapa upaya untuk meningkatkan IQ dan EQ adalah terapi akupuntur dengan metode Yamamoto New Scalp Acupuncture (YNSA) dan hipnoterapi. Tujuan penelitian untuk mengetahui pengaruh terapi akupuntur metode YNSA dan hipnoterapi untuk meningkatkan IQ dan EQ anak di TK Kanisius, Sukoharjo. Metode penelitian merupakan penelitian kuantitatif pre dan post test design dengan kontrol secara crosssectional. Analisis statistik menggunakan uji Mann Whitney dan uji paired T- test. Hasil penelitian menunjukkan untuk $p$ value pada variabel IQ yaitu komponen pemahaman: 0.018, ingatan: 0.000, logika: 0.174, daya cipta: 0.361, dan pengetahuan umum: 0.024. Hasil $p$ value pada variabel EQ yaitu komponen pengaturan diri: 0.017 , interaksi sosial: 0.661, kemandirian: 0.000, kompetisi: 0.192, kepekaan: 0.000. Kesimpulan penelitian ini adalah ada pengaruh terapi akupuntur metode YNSA dan hipnoterapi terhadap peningkatan IQ (pemahaman, ingatan, pengetahuan umum) dan EQ (pengaturan diri, kemandirian dan kepekaan) pada anak.
\end{abstract}

Kata kunci: akupuntur metode YNSA; EQ; hipnoterapi; IQ

\section{ABSTRACT}

Intellectual intelligence (IQ) helps someone to act purposefully, think rationally, and deal with his environment effectively. Similar to IQ, emotional intelligence (EQ) is important for a person's success in empathizing, expressing and understanding feelings, controlling anger, independence, and adapting. Some efforts to increase IQ and EQ are acupuncture therapy with the Yamamoto New Scalp Acupuncture (YNSA) method and hypnotherapy. The purpose of this study was to determine the effect of acupuncture therapy using the YNSA method and hypnotherapy to increase the IQ and EQ of children at Kanisius Kindergarten, Sukoharjo. The research method was quantitative pre and post test design with cross-sectional control. Statistical analysis was using Mann Whitney test and paired $T$-test. The results showed that $p$ value on the IQ variable, the components of understanding: 0.018, memory: 0.000, logic: 0.174, creativity: 0.361, and general knowledge: 0.024. The $p$ value on the $E Q$ variable are self-regulation components: 0.017, social interaction: 0.661, independence: 0.000, competition: 0.192, sensitivity: 0.000. The conclusion of this study is there was an effect of YNSA method acupuncture therapy and hypnotherapy on increasing $I Q$ (understanding, memory, general knowledge) and $E Q$ (self-regulation, independence and sensitivity) in children.

Keywords: YNSA acupuncture method; EQ; hypnotherapy; IQ 


\section{PENDAHULUAN}

Kecerdasan intelektual (IQ) merupakan kecerdasan yang menuntut pemberdayaan otak, hati, jasmani, dan pengaktifan manusia untuk berinteraksi secara fungsional dengan yang lain. Kecerdasan seseorang banyak dibentuk dan dipengaruhi faktor lingkungan antara lain keluarga dan sekolah. IQ tidak mempengaruhi perilaku etis, sedangkan kecerdasan emosional (EQ) dan kecerdasan spiritual (SQ) mempengaruhi perilaku etis (Riasning $d k k$, 2017).

Kecerdasan intelektual dan kecerdasan emosional saling berinteraksi secara dinamis, baik pada tingkatan konseptual maupun di dunia nyata. Tingkat kecerdasan seorang anak yang ditentukan secara metodik oleh IQ memegang peranan penting untuk suksesnya anak dalam belajar. Beberapa cara stimulasi tumbuh kembang anak atau meningkatkan kecerdasan anak adalah dengan akupresur, akupuntur, dan hipnosis rutin pada anak. Akupresur secara efektif dapat membantu peningkatan kecerdasan anak (Bastani et al, 2015).

Akupuntur merupakan metode pengobatan non farmakologis berdasarkan obat komplementer, dan telah dikenal dalam sistem perawatan kesehatan biasa (Fengge, 2012). Akupuntur telah digunakan untuk menstimulasi kecerdasan. Salah satu metode terapi akupuntur yaitu metode Yamamoto New Scalp Acupuncture (YNSA) (Yamamoto et $a l$, 2010. Pengembangan metode ini sangat bagus untuk menstimulasi kecerdasan anak (Wang, 2009).

Hipnosis merupakan metode yang sangat luas penggunaan dan aplikasinya di dalam kehidupan sehari - hari. Hipnoterapi sebagai suatu teknik terapi pikiran dan penyembuhan yang menggunakan metode hipnotis untuk memberi sugesti atau perintah positif kepada pikiran bawah sadar untuk penyembuhan suatu gangguan psikologis atau untuk mengubah pikiran, perasaan, dan perilaku menjadi lebih baik.

Tujuan penelitian untuk mengetahui pengaruh terapi akupuntur metode YNSA dan hipnoterapi terhadap peningkatan kecerdasan intelektual (IQ) dan kecerdasan emosional (EQ).

\section{METODE PENELITIAN}

Desain penelitian menggunakan quasy experiment with pre and post test with control group. Pengukuran data IQ dan EQ dilakukan sebelum dan sesudah intervensi akupuntur dan hipnoterapi. Data sebelum diberikan intervensi kelompok sebagai data pre test. Pengamatan kembali sesudah diberikan intervensi sebagai data post test.

Penelitian dilaksanakan pada bulan Februari hingga November 2020. Alat penelitian menggunakan IQ dan EQ test.

Populasi dalam penelitian ini adalah anak usia pra sekolah di TK Kanisius, Mayang, Gatak, Sukoharjo. Sampel penelitian adalah 40 anak yang diambil dengan teknik total sampling. Kriteria inklusi penelitian adalah :

a. Anak usia prasekolah $3-5$ tahun

b. Anak dan keluarga kooperatif bersedia menjadi responden

c. Anak dengan orangtua mau melakukan intervensi secara rutin

d. Anak dan keluarga mampu membaca, menulis dan berkomunikasi secara verbal dan non verbal

e. Anak dalam kondisi sehat, dapat berorientasi pada tempat, waktu dan orang.

Kriteria ekslusi adalah ada kontraindikasi akupuntur pada anak. Analisis data menggunakan uji paired T- test dan uji Mann Whitney.

\section{HASIL DAN PEMBAHASAN}

a. Analisis Univariat

1) Karakteristik responden berdasarkan jenis kelamin. 
Tabel 1. Distribusi responden berdasarkan jenis kelamin $(n=40)$

\begin{tabular}{cccc}
\hline No. & Jenis Kelamin & $\mathrm{n}$ & $\%$ \\
\hline 1 & Perempuan & 24 & 60 \\
2 & Laki-laki & 16 & 40 \\
\hline & Total & 40 & 100 \\
\hline
\end{tabular}

Distribusi responden berdasarkan jenis kelamin pada tabel 1 menunjukkan jumlah responden terbanyak adalah perempuan sejumlah $24(60 \%)$.

Perbedaan responden berdasarkan jenis kelamin sebagaimana tercantum pada tabel 1 menunjukkan bahwa secara kenyataan jumlah populasi secara global didominasi oleh perempuan. Perbedaan antara laki laki dan perempuan secara anatomi fisiologis memiliki perbedaan ditinjau dari sistem reproduksi yang berkaitan dengan fungsi faal, proses biokimiawi dan hormonal.
Distribusi responden dipengaruhi oleh kondisi geografis dan demografi wilayah suatu tempat. Hasil penelitian Monks (2002) menunjukkan perbedaan sejak permulaan pada dua jenis kelamin (matriks conditioning) yang dapat dianggap sebagai suatu dasar biologis yang memungkinkan adanya perbedaan tingkah laku antara perempuan dan laki-laki.

2) Perbedaan level Kecerdasan Intelektual (IQ) sebelum dan sesudah dilakukan tindakan terapi akupuntur metode YNSA dan Hipnoterapi.

Tabel 2. Distribusi responden berdasarkan IQ

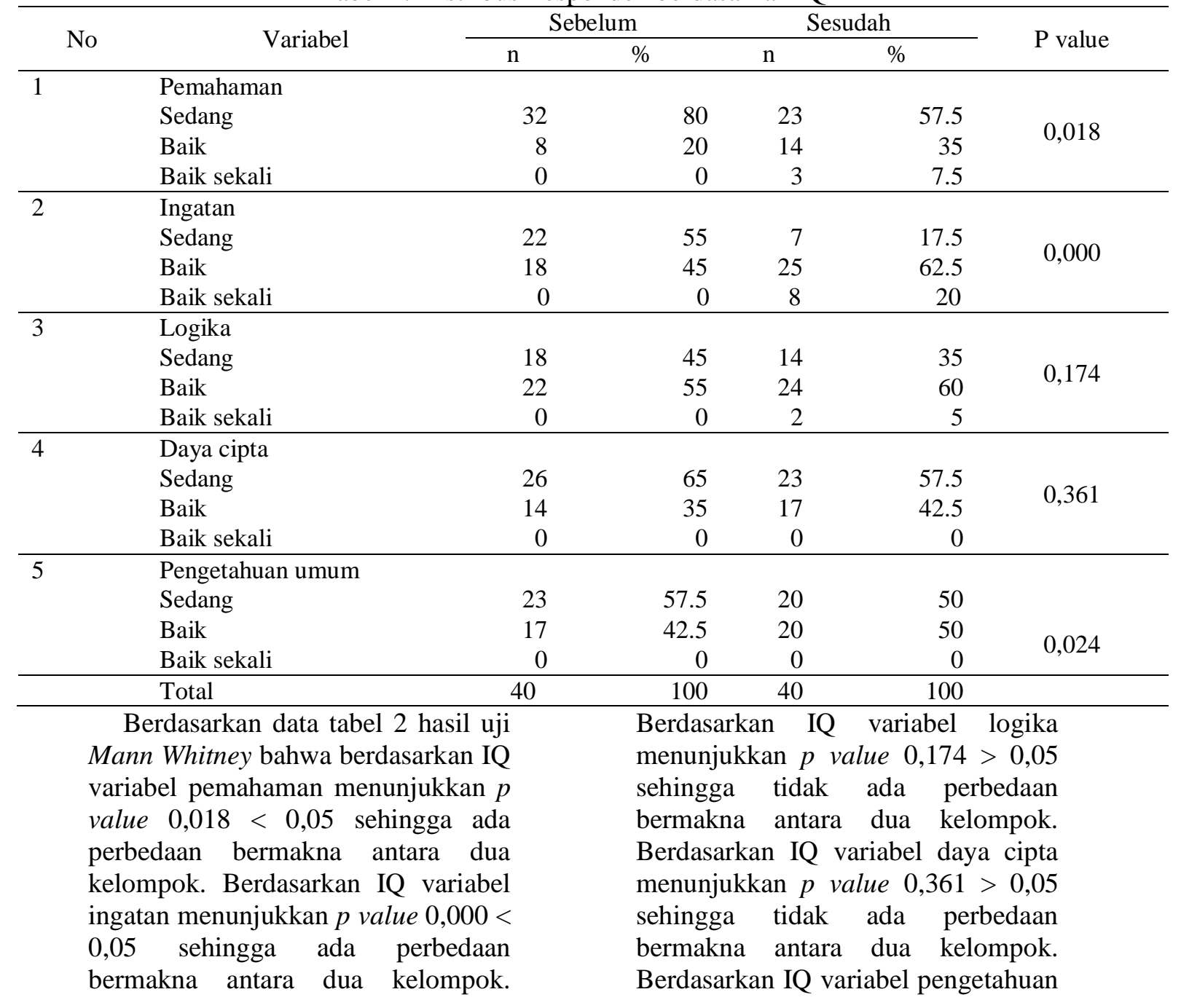


umum menunjukkan $p$ value $0,024<$ 0,05 sehingga ada perbedaan bermakna antara dua kelompok.

Hasil analisis data menunjukkan ada perubahan signifikan yaitu peningkatan IQ dari variabel pemahaman, ingatan, dan pengetahuan umum. Peningkatan komponen tersebut didapatkan karena adanya stimulasi tindakan terapi akupuntur metode YNSA secara rutin. Terapi akupuntur metode YNSA bekerja melalui sistem syaraf pusat yang mempengaruhi peningkatan aktivitas pada bagian cortical dan subcortical yaitu thalamus, lateral frontal-Dorso Lateral PreFrontal Cortex (DLPFC), insula, medial dan ventromedial prefrontal cortex, Posterior Cingulate Cortex (PCC), cerebellum, basal ganglia, dan Peri Aqueductal Grey (PAG). Aktivitas YSNA terjadi pada nosiseptif (thalamus, insula, DLPFC, PAG), area pusat motor (cerebellum, basal ganglia), dan jaringan atensi. Perubahan yang terjadi dalam aktivasi sistem nosiseptif merupakan efek langsung dari YNSA (Schockert, 2011)

Akupuntur dapat menstimulasi sistem regulasi serta mengaktifkan mekanisme endokrin dan neurologi, yang merupakan mekanisme fisiologi dalam mempertahankan keseimbangan (homeostasis) (Afrianti dan Pratiwi, 2020). Terapi ini menstimulasi sistem regulasi dan mengaktifkan mekanisme endokrin dan neurologi yang merupakan mekanisme fisiologi dalam mempertahankan keseimbangan (Syarif $d k k, 2011$ ).

Terdapat banyak teori untuk menjelaskan fungsi fisiologis akupuntur dalam mempengaruhi tubuh manusia, salah satunya adalah kecerdasan. Teori tertua adalah dalam Chinese Meredian System, yaitu titik akupuntur secara elektris dapat ditemukan dan dianggap sebagai bagian dari bidang energi elektro magnetik tubuh (Goleman,
2009). Titik-titik akupuntur sesungguhnya terletak tepat dibawah permukaan kulit, meskipun banyak titik yang berbeda yang berkaitan dengan fungsi atau bagian tubuh tertentu. Jalur syaraf merupakan struktur fisik yang mempermudah terapi akupuntur. Ujung syaraf diseluruh tubuh dihubungkan melalui spinal cord dalam sumsum belakang pada bidang-bidang tertentu dari otak dengan sistem cara dari jalur syaraf. Terdapat teori fungsi ekstrak dari system syaraf pada waktu terapi akupuntur adalah bahwa stimulasi titik-titik akupuntur tertentu mendorong cerebral cortex, hipotalamus dan kelenjar di bawah otak untuk mengurangi secara kimiawi neurotransmitter dan hormone (Xuemin, 2009). Tindakan akupuntur mampu meningkatkan sirkulasi darah lebih banyak oksigen yang dihasilkan, sehingga bisa menstimulasi dan menutrisi jaringan otak dengan baik dan mampu merangsang otak berhubungan dengan tingkat kecerdasan intelektual.

Akupuntur menunjukkan hasil yang signifikan dalam peningkatan fungsi kognitif meliputi kemampuan belajar dan daya ingat pada penelitian tentang gangguan penyakit akibat pembedahan atau penyakit kronis. Akupuntur dapat meningkatkan fungsi acetylcholinerase pada hippocampus CAI dan CA3 yang berfungsi dalam menstimulasi dan meningkatkan intelegensi, daya ingat, dan konsentrasi (Kim et al,2011).

Akupuntur dapat meningkatkan fungsi kognitif karena adanya peningkatan proliferasi sel pada beberapa region otak. Disamping hal tersebut, akupuntur juga meningkatkan kemampuan belajar yang merupakan salah satu bagian dari fungsi kognitif dengan cara meningkatkan regulasi dari glycometabolic enzyme (Liu et al, 2006). Akupuntur bermanfaat melancarkan sirkulasi darah ke jaringan otak sehingga membantu 
otak mendapatkan nutrisi yang adekuat untuk mendukung proses berpikir dan mengingat (Chen et al, 2014).

Inteligensi merupakan kemampuan yang diperoleh melalui keturunan, kemampuan yang diwariskan dan dimiliki sejak lahir dan tidak terlalu banyak dipengaruhi oleh lingkungan. Lingkungan ikut berperan dalam pembentukan kemampuan inteligensi anak. Selain hal tersebut perkembangan inteligensi juga dipengaruhi oleh stimulasi yang rutin dan bersifat kontinu.

Cara untuk menstimulasi tingkat kecerdasan intelektual lainnya yang dilakukan dalam penelitian ini adalah stimulasi dengan hipnoterapi. Pada saat hipnoterapi, simpul-simpul saraf pada anak menstimulus neurotransmitter, yaitu zat kimiawi otak yang digunakan untuk menyampaikan, memodulasi, dan menguatkan sinyal antara neuron dan sel lainnya, antara lain serotonin, dophamin, norephinephrine dan noradreanaline. Zat-zat kimiawi otak tersebut memproduksi hormonhormon yang kemudian diserap hippocampus dan didistribusikan ke seluruh sel-sel otak. Jenis hormon yang diproduksi antara lain, endorfin (hormon yang membuat hati senang, semangat dan memotivasi), encyphalin (hormon yang membuat relaks dan fokus serta konsentrasi meningkat), beta-endorfin (hormon yang membuat lebih percaya diri), dan melatonin (hormon yang membuat nyaman). Pengaruh hormon tersebut adalah mengatur katub emosi anak (Lee et al, 2008).
Hasil penelitian menunjukkan bahwa hipnoterapi lebih unggul daripada obat, plasebo, dan perawatan lainnya. Ada beberapa tahapan dalam proses hipnosis, dimulai dengan pre induction, induction, depth level test, suggestion, termination, dan posthypnosis. Keunggulan hipnoterapi yaitu menggunakan kekuatan sugesti dan kekuatan pikiran yang akan mengubah gelombang otak menjadi kondisi alfa dan teta sehingga langsung merelaksasikan kondisi pasien dan menjadi lebih nyaman dalam waktu yang lebih singkat. Selain itu, biaya hipnoterapi relatif rendah, peralatan yang digunakan sederhana, serta metode yang digunakan juga relatif sederhana sehingga mudah diterima oleh banyak orang (Khasanah dan Astuti, 2015).

Hipnoterapi dapat meningkatkan fungsi neurotransmiter sehingga jumlah hormon yang diproduksi dapat terjaga dan hippocampus mendapat asupan yang cukup. Hippocampus adalah bagian terpenting dari otak yang terlibat dalam membentuk, mengatur, dan menyimpan memori. Hipnoterapi merangsang anak secara fisiologis dan mensugesti secara psikologis, sehingga neurotransmitter akan terlatih untuk memproduksi hormon saat anak tertekan anak menjadi lebih kuat, konsentrasi, dan fokus, serta mampu berpikir logis (Yoo et al, 2016).

Tabel. 3. Distribusi Frekuensi responden berdasarkan EQ

\begin{tabular}{llrrrrr}
\hline \multirow{2}{*}{ No } & \multirow{2}{*}{ Variabel } & \multicolumn{2}{c}{ Sebelum } & \multicolumn{2}{c}{ Sesudah } & \multirow{2}{*}{ P value } \\
\cline { 3 - 5 } & & $\mathrm{n}$ & $\%$ & $\mathrm{n}$ & $\%$ & \\
\hline 1 & Pengaturan diri & & & & & \\
& & & & & & \\
& Sedang & 55 & 87.5 & 23 & 57.5 & \multirow{2}{*}{0,017} \\
& Baik & 5 & 12.5 & 10 & 2.05 & \\
& Baik sekali & 0 & 0 & 7 & 17.5 & \\
\hline 2 & Interaksi sosial & & & & & \multirow{2}{*}{0,661}
\end{tabular}




\begin{tabular}{llcrrrr} 
& Sedang & 19 & 47.5 & 16 & 40 & \\
& Baik & 10 & 25.0 & 12 & 30 & \\
& Baik sekali & 11 & 27.5 & 12 & 30 & \\
\hline 3 & Kemandirian & & & & & \\
& Sedang & 40 & 100 & 29 & 72.5 & 0,000 \\
& Baik & 0 & 0 & 11 & 27.5 & \\
& Baik sekali & 0 & 0 & 0 & 0 & \\
\hline 4 & Kompetisi & & & & & \\
& Sedang & 20 & 50 & 16 & 40 & 0,192 \\
& Baik & 20 & 50 & 20 & 50 & \\
& Baik sekali & 0 & 0 & 4 & 10 & \\
\hline 5 & Kepekaan & & & & & \\
& Sedang & 28 & 70.0 & 15 & 37.5 & 0,000 \\
& Baik & 11 & 27.5 & 19 & 47.5 & \\
& Baik sekali & 1 & 2.5 & 6 & 15.0 & \\
\hline & Total & 40 & 100 & 40 & 100 & \\
\hline & & & & anak. & Sikap tenang pada anak
\end{tabular}

Berdasarkan data tabel 3 hasil uji Mann Whitney bahwa berdasarkan EQ variabel pengaturan diri menunjukkan $\mathrm{p}$ value $0,017<0,05$ sehingga ada perbedaan bermakna antara dua kelompok. Berdasarkan EQ variabel interaksi sosial menunjukkan $\mathrm{p}$ value $0,661>0,05$ sehingga tidak ada perbedaan bermakna antara dua kelompok. Berdasarkan EQ variabel kemandirian menunjukkan $\mathrm{p}$ value $0,000<0,05$ sehingga ada perbedaan bermakna antara dua kelompok. Berdasarkan EQ variabel kompetisi menunjukkan $\mathrm{p}$ value $0,192>0,05$ sehingga tidak ada perbedaan bermakna antara dua kelompok. Berdasarkan EQ variabel kepekaan menunjukkan $\mathrm{p}$ value $0,000<0,05$ sehingga ada perbedaan bermakna antara dua kelompok.

Hasil analisis data menunjukkan ada perubahan peningkatan signifikan pada level kecerdasan emosional (EQ) dari variabel pengaturan diri, kemandirian, dan kepekaan. Peningkatan kecerdasan emosional tersebut karena adanya stimulasi berupa terapi akupuntur metode YNSA dan hipnoterapi.

Titik akupuntur YNSA dapat digunakan untuk menstimulasi kecerdasan emosional anak antara lain poin $\mathrm{A}$, poin $\mathrm{B}$, point cerebrum, point cerebellum, dan point ganglia. Pada poin tersebut bila distimulasi memberikan manfaat tenang pada anak. Sikap tenang pada anak mempengaruhi perilaku dalam kehidupan sehari-hari. Anak menjadi peka, mandiri, sadar diri, mampu berinteraksi dengan baik dan mampu berkompetisi dengan baik (Saputra dan Agustin, 2017).

Perbedaan IQ dan EQ menunjukkan bahwa IQ bersifat rasionalitas karena diperlukan untuk dapat memahami dan mempertimbangkan hal-hal yang bersifat etis dan tidak etis. Sedangkan EQ dibutuhkan untuk mengendalikan ego diri seseorang. Tingkat EQ tidak terkait dengan faktor genetik. Tidak seperti IQ yang berubah hanya sedikit setelah melewati usia remaja, kecerdasan emosi lebih banyak diperoleh melalui belajar dari pengalaman sendiri, sehingga kecakapan seseorang terus tumbuh (Jamaludin dan Indriasari, 2011).

Hipnosis merupakan metode yang sangat luas penggunaan dan aplikasinya didalam kehidupan sehari-hari. Hipnoterapi menggunakan pengaruh kata-kata yang disampaikan dengan teknikteknik tertentu melalui gelombang otaknya yang berada pada gelombang alfa atau teta, sehingga kondisinya relaks dan mudah ditanamkan sugesti.

Aligators brain yang terdapat pada anak, seperti membantah, malas, berbohong, mencuri, menjahili adik, memukul, hipersensitif dan hiperaktif dapat diatasi dengan 
metode hipnosis. Suatu pengulangan yang dilakukan dalam interval waktu yang panjang meskipun dalam kondisi sadar juga dapat menimbulkan efek hipnosis yang subminimal. Oleh kerena itu jika sugesti diberikan ke alam bawah sadar anak dalam kondisi prima hasilnya akan lebih optimal. Demikian juga dengan sugesti tentang kepekaan, kompetisi, kemandirian, kesadaran diri, serta interaksi sosial yang baik diberikan secara terus menerus akan mampu merubah karakter anak sesuai yang diinginkan (Khasanah dan Astuti, 2015).

Berdasarkan hasil analisis data menunjukkan variabel kecerdasan emosional, interaksi sosial dan kompetisi, tidak terdapat perbedaan yang signifikan, meskipun juga ada peningkatan dan perubahan ke arah perbaikan setelah dilakukan intervensi. Hal tersebut disebabkan adanya beberapa faktor lain yang mempengaruhi dan sulit dikendalikan pada penelitian ini, salah satu faktor tersebut adalah faktor lingkungan. Lingkungan merupakan faktor yang sangat menentukan tercapai atau tidaknya potensi genetik anak. Perilaku sosial dan sikap anak mencerminkan perlakuan yang diterima dirumah.

Kegiatan penelitian ini dilakukan pada masa Pandemi Covid-19, hal ini mempengaruhi kondisi lingkungan terhadap perilaku anak-anak. Pada masa pandemi anak belajar di rumah sehingga interaksi anak dan teman maupun individu lainnya menjadi terbatas. Hal ini menjadi faktor keterbatasan penelitian.

\section{KESIMPULAN}

Adanya pengaruh terapi akupuntur metode YNSA dan hipnoterapi terhadap peningkatan IQ (pemahaman, ingatan, pengetahuan umum) dan EQ (pengaturan diri, kemandirian dan kepekaan) pada anak usia pra sekolah.

\section{UCAPAN TERIMA KASIH}

Ucapan terima kasih kepada PPM Poltekes Kemenkes Surakarta dan Kepala Sekolah TK Kanisius, Mayang, Gatak, Sukoharjo serta semua pihak yang telah terlibat pada Program penelitian skema PTUPT tahun 2020.

\section{REFERENSI}

Afrianti $N$ dan Pertiwi ER, 2020, Penerapan Terapi Akupresur Dalam Penanganan Mual Muntah Pasca Kemoterapi. Jurnal Ilmiah Permas: Jurnal Ilmiah STIKES Kendal, vol.8, no. 4. hal 461-470.

Bastani F, Khosravi M, Borimnejad L, Arbabi N., 2015, The effect of acupressure on cancer-related fatigue among school-aged children with acute lymphoblastic leukemia. Iran J Nurs Midwifery Res. 2015 SepOct;20(5):545-51. doi: 10.4103/1735-9066.164508. PMID: 26457090 ; PMCID: PMC4598899.

Chen R, Chen M, Su T, Zhou M, Sun J, Xiong J, Chi Z, Xie D, Zhang B, 2014, A 3-Arm, Randomized, Controlled Trial of Heat-Sensitive Moxibustion Therapy to Determine Superior Effect among Patients with Lumbar Disc Herniation. Evid Based Complement Alternat Med. 2014;2014:154941. doi: 10.1155/2014/154941. Epub 2014 Jul 24. PMID: 25152757; PMCID: PMC4131491.

Fengge, A 2012, Terapi Akupresur: Manfaat \& Teknik Pengobatan. Crop Circle Corp, Yogyakarta 104 hal. ISBN 978-602-99823-1-2

Goleman, D 2009, Kecerdasan Emosi : Mengapa Emotional Intelligence lebih tinggi daripada IQ. Jakarta: PT.Gramedia Pustaka Utama.

Jamaluddin J dan Indriasari R, 2011, Pengaruh Kecerdasan Intelektual, Kecerdasan Emosional, dan Kecerdasan Spiritual terhadap Etika Mahasiswa Akuntansi Fakultas Ekonomi Universitas Tadulako, Jurnal PAMATOR, Jurnal Ilmiah Universitas Trunojoyo Madura, Vol 4, No 1, hal 46-56 
DOI: https://doi.org/10.21107/pamat or.v4i1.2442

Khasanah L and Astuti R, 2015, "Efektivitas Akupresur Dan Hipnoterapi Dalam Mengatasi Dismenore Pada Remaja Putri Di SMK Muhammadiyah Salaman", Journal of Holistic Nursing Science, 2(2), pp. 1-9. Available at: https://journal.unimma.ac.id/index .php/nursing/article/view/1806

Kim H, Park HJ, Shim HS, Han SM, Hahm DH, Lee H, Shim I., 2011, The effects of acupuncture (PC6) on chronic mild stress-induced memory loss. Neurosci Lett. 2011 Jan 25;488(3):225-8. doi: 10.1016/j.neulet.2010.09.080. Epub 2010 Oct 12. PMID: 20946936.

Lee, J, Dodd, M, Dibble, S, Abrams, D, 2008, Review of acupressure studies for chemotherapy-induced nausea and vomiting control. $J$ Pain Symptom Manage 2008; 36(5):529544.

https://doi.org/10.1016/j.jpainsymma n.2007.10.019

Liu CZ, Yu JC, Zhang XZ, Fu WW, Wang T, Han JX, 2006, Acupuncture prevents cognitive deficits and oxidative stress in cerebral multi-infarction rats. Neurosci Lett. 2006 Jan 23;393(1):45-50. doi: 10.1016/j.neulet.2005.09.049. Epub 2005 Oct 19. PMID: 16236447.

Monks,F.J., 2002, Psikologi Perkembangan : Pengantar Dalam Berbagai Bagiannya. Cet,14 Yogyakarta : Gajah Mada University Press.

Riasning, N. P., Datrini, L. K. and Wianto, I. M. ,2017, "Pengaruh Kecerdasan Intelektual, Kecerdasan Emosional Dan Kecerdasan Spiritual Terhadap Sikap Etis Mahasiswa Akuntansi Di Kota Denpasar", KRISNA: Kumpulan Riset Akuntansi, 9(1), pp. 50-56. doi: 10.22225/kr.9.1.328.50-56.
Saputra \& Agustin,2017, Akupuntur Dasar, Surabaya : Airlangga University Press.

Schockert, T, 2011., Yamamoto New Scalp Acupuncture (YNSA): Development, principles, Safety, Effectiveness and Clinical Applications, Acupuncture Clinical Practice, Praticular Techniques and Special Issues, Prof. Marcelo Saad (Ed.), ISBN: 978-963-307-630-0, InTech

Syarif, H., Nurachmah, E., \& Gayatri, D. ,2011, Terapi Akupresur Dapat Menurunkan Keluhan Mual Muntah Akut Akibat Kemoterapi Pada Pasien Kanker: Jurnal Keperawatan Indonesia, 14(2), 133-140. https://doi.org/http://dx.doi.org/10.74 54/jki.v14i2.321.

Wang, Yuyang, 2009, Microacupuncture In Practice. St. Louis : Chuchill Livingstone, Elsevier

Xuemin,Shi,2007, Acupuncture and Moxibustion, Beijing : National Planned University Textbooks for International Traditional Chinese Medicine Education.

Yamamoto, Toshikatsu, Helen, Yamamoto. 2010, Yamamoto Margaret Michiko: Yamamoto New Scalp Acupuncture (YNSA). Miyazaki Minami Printing Co., Ltd.

Yoo JE, Yun YJ, Shin YB, Kim NK, Kim SY, Shin MJ, Yu SA, 2016, Protocol for a prospective observational study of conventional treatment and traditional Korean medicine combination treatment for children with cerebral palsy. $B M C$ Complement Altern Med. 2016 Jun 8;16:172. doi: 10.1186/s12906-0161161-6. PMID: 27267182; PMCID: PMC4897905. 